Article

\title{
Defining the Requirements of an Information System for Climate Change Adaptation in the Mountain Communities of Dolakha, Nepal
}

\author{
Adish Khezri ${ }^{1, *}$, Rohan Bennett ${ }^{2}$ (D) and Jaap Zevenbergen ${ }^{1}$ \\ 1 Faculty of Geo-Information Science and Earth Observation (ITC), University of Twente, P.O. Box 217, \\ 7500 AE Enschede, The Netherlands; j.a.zevenbergen@utwente.nl \\ 2 Swinburne Business School, PO Box 218 Hawthorn, Victoria 3122, Australia; rohanbennett@swin.edu.au \\ * Correspondence: a.khezri@utwente.nl; Tel.: +31-61-675-6539
}

Received: 30 April 2018; Accepted: 28 May 2018; Published: 1 June 2018

check for updates

\begin{abstract}
Community-based Adaptation Programs (CAPs) that involve the participation of communities are being actively promoted in mountainous areas. These areas are climate sensitive and are often heavily influenced by landslides, floods, and drought. This research indicates that designers of adaptation programs seek to develop and implement CAPs based on international viewpoint and their obligations, but not community requirements. Such CAPs create uneven access to information resources for communities and do not implicitly reduce community vulnerability. In response, the research proposes the establishment of an Information System (IS) to support delivery of reliable climate adaptation services to mountain communities. This research uses Nepal as a case study that experiences a lack of effective adaptation programs due to its varied topography, prevalent climate-related disasters, and barriers in capacity building and institutional development. The results of the analyses indicate that the national level focuses on preparing adaptation action plans, whilst district levels and Non-Governmental Organization (NGO) focus on facilitating adaptation implementation for community and individuals. Additionally, the results reveal that an IS can enhance the design and implementation of CAP. Finally, the results are used to articulate prioritized services for an IS to assist communities who are in the greatest need of climate service delivery.
\end{abstract}

Keywords: information system; information system requirements; community-based adaptation program; mountain communities; climate change

\section{Introduction}

The Community-based Adaptation Program (CAP) is an emerging concept that can play a key role in responding to climate change. At the international level, there are many policy solutions and top-down implementations that emphasize the importance of CAP [1]. A growing number of National Adaptation Programs of Action (NAPA) and Local Adaptation Plans for Action (LAPA) also focus on CAP. Many mountain communities participate in CAPs: the "small-scale, place-based, grassroots-driven and lesson-based approach" [2] aligns with the prevailing livelihoods and vulnerabilities in those locations. Mountainous areas are fragile ecosystems defined as including a general prevalence of natural disasters [3], less human capacity to respond to environmental degradation threats [4] and an early indicator of climate change [5]. They are sources of water, energy, biodiversity, forest and agricultural products amongst others. This remarkable combination of resources makes them susceptible to environmental and economic breakdown [6]. Mountain CAPs tend to focus on community vulnerability reduction and emphasize the need for collective action by focusing on community adaptation efforts-ones that bring the benefits directly to the members of the communities and thereby facilitate rural development [7]. 
A variety of actors and funding mechanisms at various levels are involved in the development and implementation of CAPs for mountainous areas. Mountain individuals and communities are at the front line and react to the adverse effects of climate events, based on the resources available. The local level acts as a mediator between national and community levels for CAP budget allocation. Meanwhile, the national level develops the climate-related policies that are implemented lower down. The international level focuses on climate change negotiations and increasingly distributes funds to facilitate CAPs [8]. Therefore, CAPs involve the complex and interdependent hierarchy of actors: identifying an adaptation programs' needs and requirements, especially for mountain communities and individuals, is a complicated activity: the local level is often considered the last component of this hierarchy and the final operational level of a CAP.

Successful mountain CAP implementation requires local governments to take responsibility in translating top-down national or regional adaptation policies and financing communities and households in bottom-up adaptation actions. Experiences from adaptation programs reveal that local government is a key actor; however, these organizations often experience difficulty accessing resources and have the limited capacity [9]. Moreover, they face challenges in gaining the support of national and international levels-especially in more inaccessible and less developed countries [10].

In resolving some of the above-mentioned problems much work in the sector has focused on developing plans and policies, climate change modeling and monitoring tools, spatially integrated tools and information tools. In this regard, the interdisciplinary area of Information Systems (IS) [11] appears to be a promising domain to a supportive socio-technical framework for integrating "hardware, software, data, people, and procedures" [12]. IS cuts across almost all sectors including tourism [13], economics, natural sciences, computer science, communications [14] and complex systems such as climate change [15]. Its core describes the exchange of information and availability of service/s based on user requirement/s.

The United Nations Framework Convention on Climate Change (UNFCCC) endorses community access to climate information and services through the development of technical tools and methodologies. Climate services refer to information about climate change and its impacts [16]. This information has the potential to enable mountain communities to prepare themselves for climate change events. Communities require information on past, present, and future of climate variables. Improvements in agriculture, water availability, and sustainable land use are directly related to information about land and climate. The UNFCCC acknowledges the importance of climate information and demands climate services mainly related to adaptation activities [17]. This paper focuses on limitations in existing land and climate change services that support mountain communities for CAP initiatives and seeks to identify areas for improvement, primarily based around appropriate information provision and IS application. Therefore, land and climate change IS are needed to supply the required information and data services, based on mountain communities' needs, to increase their adaptive capacity. This paper also explores if the potential role of IS is appropriately considered in CAP theories and practice (using Nepal as an area of focus) and its requirements. As such, Section 2 reviews adaptation initiatives, adaptation needs, and options-including existing tools. Section 3 explains the materials and methods including a description of criteria for study area selection, the study area itself, data collection activities including the questionnaire developed, and the subsequent data analysis. Section 4 presents the analysis of the in-depth interviews undertaken with key experts from NGO, local and national levels, Focus Group Interviews (FGI) and household surveys.

\section{Adaptation Initiatives}

There are many policy statements-and top-down approaches at international level-that emphasize the need for CAP [1]. The UNFCCC suggests the development of adaptation programs should be action-oriented and country-driven. In response, nations make efforts to develop different adaptation tools and methods to deal with climate change problems [18-20]. Specific to mountainous countries, NAPA, LAPA and climate change policy have been developed as strategic adaptation tools. 
CAP is discussed as a participatory and coordinated approach where government agencies, ministries, local municipalities, NGOs, communities and the private sectors are all stakeholders-and involved in development [10,19].

\subsection{Adaptation Needs and Options}

Adaptation needs arise when the impacts of climate change require action to safeguard populations, assets, ecosystem and their services [20]. Adaptation focuses on environment and society. Climate change potentially alters ecosystem services and biodiversity [21] and reduces access of marginalized people to basic services [22]. Sound adaptation relies upon networks of actors at international, national and local levels to provide guidelines, regulations, and policies [23]. Institutions support adaptation funding and promote the design and implementation of adaptation [24]. Technology and information can provide more accurate observations regarding climate variables [25]. Information sharing can support making sound decision/s in promoting vulnerability and impact assessments. It can enhance a communities' adaptive capacity [26]. Information sharing defines where and why communities are involved, what role they are playing, what resources they are using, and for how long. The information enables improvements of community capacity, and identifying available resources and adjusting to new situations.

Identification of adaptation needs is usually based on impact assessments [27] and/or resilience assessments [28]. Over time, adaptation needs tend to have moved from focusing on environmental, social and economic drivers of vulnerability, to underlying causes of vulnerability including "informational, capacity, financial, institutional, and technological needs" [29].

A wide range of adaptation options is identified in the literature. Engineering solutions such as building codes and seawalls [30], floating gardens [31], ecosystem services [32], alerting systems [33], incentives such as taxes, subsidies and Payment for Environmental Services (PES) [34], amongst others [35], are some of the actions by means of adaptation options. Most adaptation options are "discrete activities" and have "concrete outcomes" that are defined in "scope, scale and time" [36]. On these initiatives, Noble et al. [10] argue that most adaptation programs are overlapping, need prerequisites, do not meet adaptation needs, are impossible to implement or poorly developed - particularly in the least developed countries. In addition, existing adaptation options are said to be mostly sector-specific or location-specific. Having said this, CAPs for mountain areas are probably most useful when they are tailored to meet mountain communities' (user) need/s. This is more likely to increase community involvement, add value to community achievements, and makes adaptation successful.

\subsection{Adaptation Tools}

Adaptation tools and methods, a specific type of adaption option, are defined as adaptation strategies and/or as plans of action [37]. "Sector-specific" tools include agriculture (smart agriculture), water (watershed management), coastal resources (shoreline management), human health (mapping disease) and terrestrial vegetation (agro-ecological zones) [38].

Interactive geo-design tools can be applied to support decision-makers at the local level [39]. Decision support tools screen risks and support adaptation strategies such as Community-based Risk Screening Tool-Adaptation and Livelihoods (CRiSTAL) [40]. Planning tools monitor and model climate change and its impacts: SERVIR provides a prime example. It is a spatially integrated tool that detects changes in land, forest and water resources at regional levels [41]. There are also examples of innovative information dissemination tools at different administrative levels. weADAPT is an "open space" climate adaptation platform. It connects researchers, policy makers and active adaptation practitioners on a global scale to learn and share adaptation case studies. weADAPT consists of searchable adaptation layers [42]. The Adaptation Learning Mechanism (ALM) is another adaptation knowledge-sharing information platform to exchange adaptation experiences on a global level [43]. AfricaAdapt is a network that focuses solely on Africa about "the flow of climate change adaptation 
knowledge for sustainable livelihoods" between policy makers and civil society groups. It is a web-based application that includes videos, offline activities such as radio programs in local languages and face-to-face interactions and represents climate variability [44].

IS as a generalized concept, looks promising with regards to CAP implementation. It has the capability of information retrieval and information management [45], promoting sharing and exchange of information [46] and translating information [10]. Geographic Information System (GIS) applications and Information and Communication Technologies (ICTs) tools are popular to facilitate communities preparedness for climate change related events [44,45].

In summary, a wide array of adaptation tools is available [47]. However, there are limits, barriers, and costs associated with each. Sector-specific tools only cover the common sectors. Decision support tools are usually focused on one-way communication and are product-focused [48]. Planning tools are generally designed by multiple stakeholders, and although not specifically focused on climate change [49], they are suitable to assist data and information for adaptation. Most innovative information dissemination tools are designed on global and regional scales: they are not simple and/or useful for communities to perceive. Also, the tools that are emerging remain geared towards scientific communities and present information from/for scientific perspectives [50] and not necessarily fit with the on the ground community needs [51]. These tools introduce different adaptation actions that require various tools, resources, skills, scientific and comprehensive experiences: they do not necessarily bring benefits for communities/individuals concerning development as a goal of CAP. Literature reveals that decision makers in practice are the ones that are actually seeking climate information to support the environment and plan strategies at their level of interest [50].

\section{Materials and Methods}

This paper explores the limitations of existing climate change adaptation tools. It investigates the possibility and need for an Information System (IS) through evidence-based design and implementation of CAPs based on relevant and highly granular spatial data and services. Specifically, the paper focuses on mountain communities' requirements that are relevant for prioritizing services required for Mountain Community Adaptive System (MCAS). In response, the exploratory case study approach was identified as being commensurate to the fulfilment of the aims. A case study can "contribute to our knowledge of individual, group, organizational, social, political and related phenomena" [52], such as a mountain community. The use of the exploratory case study, involving primary research, enabled focusing on a specific unit of analysis and a particular location. It enabled the capture and assessment of qualitative data, concerning understanding the limitations of existing tools and potential enhancements enabled by IS. Figure 1 presents the overview of the research methodology conceptually.

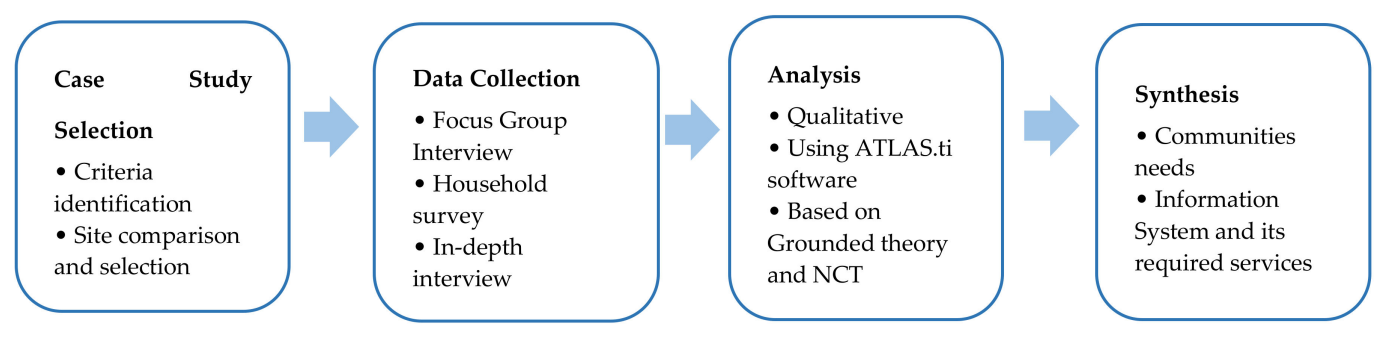

Figure 1. Overview of research methodology.

\subsection{Case Study Selection and Criteria Identification}

From an initial subset of countries with known predomination of mountainous communities, Nepal was selected. Key criteria for selection included its engagement (or lack thereof) in existing CAP initiatives, adequate levels of safety and security, large sample selections regarding numbers and diversity of mountainous communities, and proximity and availability to the research team. Nepal has 
climate change policies, NAPA, LAPA and laws specifically focused on adaptation. This compares favorably to the other member countries of the Hindu Kush Himalayan (HKH) region-Afghanistan, Bangladesh, Bhutan, India, Myanmar, and Pakistan. These legal instruments support plans and programs for mountains' people resilience [53]. Nepal ranked 120 amongst 181 countries based on The University of Notre Dame Global Adaptation Initiative (ND-GAIN) Index. This rank represents a combination of Nepal's vulnerability to climate change and its readiness (ability to convert the investment to adaptation). Nepal ranked 24 in Climate Risk Index for 1996-2015 [54] and 71 in the least ready country [55] for adaptation to climate change. Nepal's high vulnerability (rank 129) and high readiness (115) of ND-GAIN Matrix Index emphasizes that it is responding to the effect of climate change, but it needs urgent and greater adaptation actions [55]. Rural mountain communities face poverty which is increased through factors such as "remoteness, poor accessibility, the fragility of the ecosystems, and marginalization" [56]. About 80\% of Nepal's population resides in rural areas [57] that hampers them in climate change adaptation. It is difficult to inform and train rural mountain communities about adaptation programs, design and implementation of CAP because of lack of infrastructure such as roads, power and energy lines. Therefore, many of them are not involved in CAP.

\section{Specific Study Area Selection}

The Dolakha district of Nepal with Charikot as its district headquarters was selected for data collection. The specific case helps to bridge the gap between the literature review and the real world [58]. The area is ranked: (a) very highly vulnerable in overall Vulnerability Index of Nepal, (b) highly vulnerable in Combined Risk Index including flood, drought, landslide, ecological, temperature, rainfall and Glacier Lake Outburst Flood (GLOF) and (c) prioritized district for adaptation planning [59]. Dolakha district with an altitude of $2088 \mathrm{~m}$ and a population of 186,557 [60] is located in latitude $27^{\circ} 46^{\prime} 42.24^{\prime \prime} \mathrm{N}$ and longitude $86^{\circ} 10^{\prime} 30.72^{\prime \prime} \mathrm{E}$ in central development region, Janakpur zone, mountain physiographic area, in the central east part of Nepal [61]. Dolakha's average temperature was $14{ }^{\circ} \mathrm{C}$, and its average rainfall was $324 \mathrm{~mm}$ between 2009 to 2016 [62].

Three Village Development Committees (VDCs), Charikot (Bhimeshwar municipality), Susma chhemawati and Bocha were selected based on the following criteria: (a) accessibility-easy to access rural, remote mountainous areas, (b) scale of the field work support, (c) highly susceptible to extreme drought and rainfall. The total number of households is 6076 in Charikot, 775 in Bocha and 864 in Susma chhemawati. The average household sizes in the selected VDCs are 3.71, 3.61 and 3.98, respectively. In the three mentioned VDCs: firewood is the primary fuel used for cooking, electricity is the source of light, tap water is the source of drinking water, radio, mobile phone, and television are the main communication facilities, the major casts are Chetree in Charikot and Bocha, and Thami in Susma chhemawati, the dominant language is Nepali in Charikot and Bocha, and Thami in Susma chhemawati, and more than half of the population living in the three VDCs are literate [63]. Figure 2 presents Dolakha district in Nepal. 


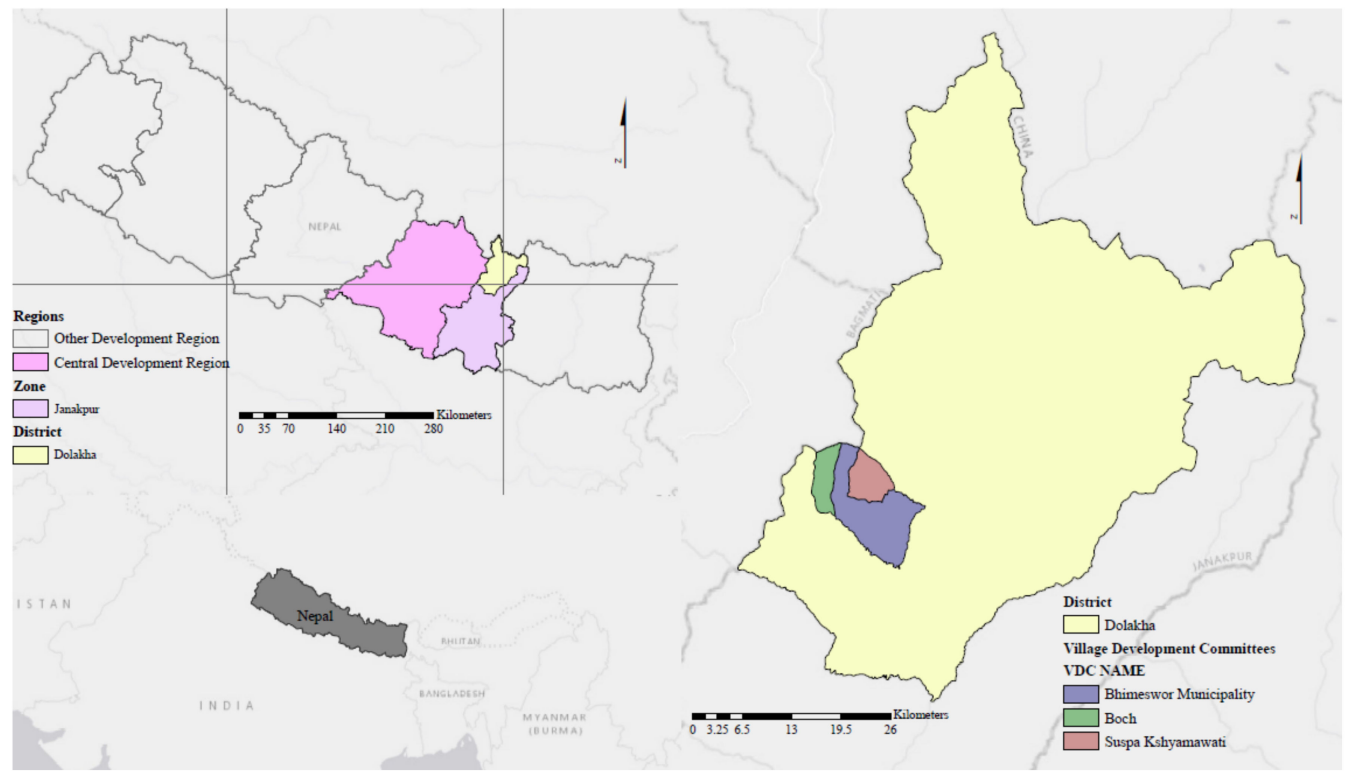

Figure 2. Dolakha district, Nepal.

\subsection{Data Collection}

The research method applied consists of FGI with local communities and a household survey with local residents to identify if and how they are involved in CAP. Additionally, a series of qualitative in-depth interviews were carried out with key local experts of the district offices and an NGO at Charikot, Dolakha district headquarters. For validation of CAP and its services, key national experts of the sectoral ministries and departments were interviewed in Kathmandu, Nepal.

\subsubsection{Focus Group Interview and Household Survey}

FGIs with the local communities of Bocha $(n=21)$ and Charikot $(n=19)$ coupled with 29 household surveys with local residents of the three selected VDCs were carried out to explore their involvement in CAPs and adaptation service/s delivery. The NGO recommended the three VDCs on account of them being closely involved in the implementation of climate adaptation activities. In addition, it was easier accessing them with due consideration to the road system in Dolakha district. The selection of household survey was based on one household per a community: during conducting fieldwork it was confirmed that each community consisted of eight to thirteen households. Prior to data collection, different sets of open-ended questionnaires were designed based on secondary data sources for each level of national, district, community and individual. These questionnaires focused on various aspects including adaptation programs, climate change evidence/policy, land policy/tenure, community life and livelihood/vulnerability, adaptive capacity and data and information system. A literature review, desk research and the theoretical background of each level revealed the different stakeholders and their roles and responsibilities relative to CAP. These were used to map the understanding of the interviewee(s). Prior to FGI, being a member and non-member of the Forest User Group (FUG), number of participants (between 6 to 10) [64], gender-issues (equality in male and female participants), participants professions (farmer, housewife, teacher, seller and worker) and their ages (youth, adults and senior) were taken into consideration. For this paper, we only analyzed the questions related to the impacts of climate change, mountain community vulnerability, and roles and responsibilities in the design and implementation of CAP; all, to explore if current $\mathrm{CAP} / \mathrm{s}$ were in line with mountain communities' needs and requirements. 


\subsubsection{In-Depth Interview}

In-depth interviews, the ministries, the district offices, and an NGO were undertaken because they play an essential role in CAP and increasing mountain community adaptive capacity. The Ministry of Science and Technology (MoST, Katmandu, Nepal) was chosen as the developer of NAPA [65]. The Ministry of Agriculture and Development (MoAD, Katmandu, Nepal) and the Ministry of Forest and Soil Conservation (MoFSC, Katmandu, Nepal) are the key stakeholders of Thematic Working Groups (TWG, Katmandu, Nepal) of NAPA. The Department of Hydrology and Meteorology (DHM), under the Ministry of Environment and Government (MoEG, Katmandu, Nepal), provides data and information about rainfall and temperature. The Ministry of Land Reform and Management (MoLRM, Katmandu, Nepal) was selected since climate change is happening on land and land is the unique source of life [66].

The district offices create links between community and national level. The District Planning Office (DPO) is the head of all district offices. The District Forest Office (DFO) and the District Agriculture Development Office (DADO) were selected as forest, and agriculture products are influenced by the impacts of climate change. Community forest management is quite successful in Nepal [67] and agriculture provides 33\% of Gross Domestic Product (GDP) in Nepal [68]. The District Livestock Office (DLO) was chosen as climate change has an impact on livestock. The District Survey Office (DSO) provides cadastral and land use maps that play a vital role in the design and implementation of adaptation programs. The Federation of Community Forestry Users Nepal (FECOFUN) is an active NGO in Dolakha for poverty reduction and provides opportunities for communities through REDD+.

\subsection{Qualitative Data Analysis and Synthesis}

The qualitative interviews were analyzed using ATLAS.ti. to address the issues related to development and implementation of CAP/s and MCAS requirements. The relevant data was collected and organized for a comprehensive analysis of specific details [69]. Data entry processes were undertaken and intended to ensure data accuracy and to remove the incompleteness of collected data during the fieldwork. Collected data from the fieldwork were qualitative. NCT was utilized as a method for qualitative data analysis and research software in ATLAS.ti. NCT stands for Noticing (quotation), Collecting (coding) and Thinking (finding patterns in data). Qualitative data analysis requires extensive data-visiting and code-defining, re-visiting and revising coded-data or re-analyzing. The steps to analyze narrative descriptions are: coding that is labeling segments of transcriptions based on a specific objective, conceptualizing that refers to the named themes in the research study, the categorization that are classified codes and Grounded theory. Transcriptions of in-depth interviews, FGIs and household surveys were coded in line with CAP. The methodology followed for each transcription was based on an analytical framework to search for CAP considering IS and its requirement/s. Therefore, an inductive research approach was taken to identify the impacts of climate change, community vulnerability, CAP strategy, stakeholders' roles and responsibilities, and their recommendation/s to improve the design and implementation of CAP. Grounded theory was taken as an approach to identify the code frequency [70] and to find the key adaptation services that the communities and individual/s need to place in CAP.

It is possible to integrate data segmentations during the process of data analysis in ATLAS.ti. to make a "system of linkages" [70]. The linkages are a holistic approach toward the understanding of the qualitative data. The linkages display network views that allow the analyzer to find the relationships among data segments. To create a network view, first, the documents of FGI, in-depth interview of NGO, district and national key experts were grouped according to a shared code of recommendations. Therefore, it was possible to associate all recommendations to one recommendation code. Next, the recommendations were linked together if they were similar, support or contradict each other. Accordingly, a convenient cluster of recommendations was created rather than being distributed among the documents that made finding the results easier. The network view and clustering also applied to current CAP strategy. Next, the main findings of the analysis were revisited, and the 
concept of an integrated land and climate change IS was hypothesized and conceptualized, based on communities requirements.

\section{Results and Discussion}

This section presents the results of the summarized analysis of FGI with communities, the household survey and in depth-interview with NGO, district, and national key experts. Recommendations and CAP strategies are presented separately or as a group in each section based on the criteria mentioned in qualitative data analysis and synthesis.

\subsection{Results of Focus Group Interview with the Communities}

\subsubsection{Charikot}

Impacts of climate change: shorter rainy seasons and less paddy production, less amount of rain compare to the past and no snow in the winter.

Community vulnerability: power struggle promotes inequality in getting high-quality seeds, lack of pasture land for their cattle due to community forest management, harder grass (cannot be eaten by cattle) and difficulty in tilling soil due to chemical fertilizers.

Existing CAP involvement: utilizing chemical fertilizer and modified seeds, harvesting water in small tanks, taking part in raising awareness programs to improve their knowledge about climate change.

\subsubsection{Bocha}

Impacts of climate change: inconsistency in rainfall, rising temperature, changes in monsoon time, melting snow, water deficit, landslides, and erosion.

Community vulnerability: human health problems including difficulty in breathing due to dust and pollution, less animal productivity including cow and buffalo, more livestock miscarriage, unexpected trees blooming, increasing mosquitos and diseases in crops, soil degradation, lack of infrastructure including road and proper market to sell their agricultural products.

Existing CAP involvement: livestock treatment, using organic fertilizer and hybrid seeds, bio-engineering (bamboo and cardamom) to stop erosion, soil treatment, building fences to prevent landslides, poultry and goat farming, listening to TV and FM radio mobile programs about climate change.

\subsection{Results of the Household Survey in Three VDCs}

\subsubsection{Susma Chhemawati $(n=11)$}

Impacts of climate change: landslide, water deficit, drought, heavy rainfall during monsoon and shorter rainy seasons compare to past.

Community vulnerability: livestock disease including Blackwater fever $(n=2)$, loss of land $(n=8)$, damage in crops including potato $(n=4)$ and farm fruits such as apple $(n=1)$, less agricultural products including paddy, millet and maize $(n=11)$, no information about the effects of climate change $(n=6)$.

\subsubsection{Bocha $(n=8)$}

Impacts of climate change: heavy snow compare to previous years, shorter rainy season, landslides because of heavy rainfall, less visibility due to the increasing amount of fog and dust.

Community vulnerability: livestock disease including Blackwater fever $(n=1)$, damage in crops including potato and cauliflower $(n=4)$, no information about the effects of climate change $(n=4)$.

\subsubsection{Charikot $(n=10)$}

Impacts of climate change: frequent rainstorm, rising temperature, cold seasons, flood, drought, landslides, and air pollution due to dust. 
Community vulnerability: livestock disease including Blackwater fever $(n=3)$, failure in paddy $(n=7)$, no information about the effects of climate change $(n=6)$.

Only 6 out of 29 respondents are involved in bio-engineering and building fences as a part of CAP involvement.

\subsection{Results of the In-Depth Interview with FECOFUN (An NGO)}

Impacts of climate change: less rainfall pattern compare to baselines, erosion, and landslides, low rate of fertility both in agriculture and livestock, increasing numbers of pests and weed.

Community vulnerability: insufficient agricultural products, lack of planning and implementation of adaptation by the government or the civil society.

Existing CAP involvement: raising community awareness on carbon reduction, forest fire, and overgrazing, conducting bio-engineering (bamboo and cardamom), renovating communities stove, using bio-fuel and biogas.

\subsection{Results of the In-Depth Interview with District Key Experts}

DLO is involved in livestock treatment, training farmers on keeping their livestock safe and passing livestock problems to MoAD through the regional directorate.

DADO is involved in mandatory programs-providing seeds, training farmers in a technical way regarding cultivating vegetable and small irrigation schemes.

DFO is responsible for Reducing Emissions from Deforestation and forest Degradation (REDD+) and directing communities on harvesting forest products.

DSO supplies cadastral maps and land-related data.

DPO is an entry point for district offices to prioritize plans and programs. This office trains mountain communities in improving their livelihood through Citizen Awareness Center (CAC), supports mountain community through social security programs, crops and fruits planting.

\subsection{Results of In-Depth Interview with National Key Experts}

MoSTE contributes to the development of climate change policy, NAPA, LAPA, low carbon strategy and allocating a budget for mountain community vulnerability reduction.

MoFSC is responsible for mitigation policy development.

MoAD developed National Agriculture Policy (NAP). This office is involved in agro-business, micro-insurance schemes, goat, and vegetable farming.

MoLRM is responsible for the development of Land Use Policy (LUP), producing topographic maps and cadastral data, and management of LIS.

DHM provides rainfall and temperature, wind, solar radiation and evapotranspiration data.

It became clear that except $\mathrm{NGO}, \mathrm{MoAD}$, and $\mathrm{DADO}$, there are no CAP strategies at district and national level. MoAD and DADO have an indirect involvement with current CAPs as a part of their responsibilities. Additionally, almost every source recommended the need of a system for instant communication of information such as potential resources. The system facilities communities to diversify their livelihood to ensure their income generation. NGO, several national and district offices highlighted the need of practicing land and forest use rights/lease to make access to suitable land easier. Communities can expand agro-business and manage vacant lands this way. Different types of weather, climate change data, CAP policies, plans, and programs were mentioned as crucial information for increasing local awareness and building mountain communities' capacity.

\section{Key Findings}

Results of the in-depth interviews at national offices revealed that ministries are not involved in CAP: they focus mostly on the development of different climate-related policies-based on their roles and responsibilities. These policies do not necessarily cover communities' needs in CAP. For instance, Nepal climate change policies were developed to implement the provisions of Kyoto Protocol [71]. 
The objectives of Nepal's NAPA are reducing poverty in mountainous regions and progressing the Nepal development process [65]. The experts suggested that climate-related policy development needs the results of vulnerability assessment, climate disaster management, and risk information.

The national key experts at MoSTE mentioned that $80 \%$ of the total climate change fund is allocated to the implementation of programs at the community level. They added that LAPA is also developed to support CAP and delivery of adaptation services to mountain communities. These findings highlight that there are no budget or policy barriers to the involvement of district offices in CAP. However, the results of the in-depth interviews at district offices and NGO revealed that only DADO (as its responsibility) and the NGO were involved in CAP. Importantly, of the two, neither consider or utilize IS in CAP implementation.

Results of FGI showed that communities are involved in some pre-defined CAPs based on their needs and the resources available. NGO is more active in Bocha than its headquarters (Charikot). Therefore, Bocha community gets more information on accessing resources and using them better. It reduces climate vulnerability and the risks they face. The Bocha community generates money using poultry and goat farming, by selling chickens, goats and their products. This cash income enables communities to insulate their houses against heat and cold, to add facilities to them including bio-stove/electrical stoves and water tanks that support their health and water deficit, respectively. The communities indicated that information about adaptation strategies and climate change policy add value to their life. For instance, this information ensures improvement in communities' agricultural products. They can identify better places to cultivate what products and when to invest in different agricultural products and the best time and ways of harvesting forest and agricultural products. Results of the household survey showed that a minority of individuals are involved in some of CAP offered by an NGO-36\% in Susma chhemawati, 12.5\% in Bocha and 40\% in Charikot. Membership is necessary to be involved in CAP/s. Lack of money to become a member and not having information on adaptation activities hamper individuals in CAP implementation. Since people are engaged in income generation business in Charikot, they are reluctant to participate in CAP. Individuals proposed to identify information on how to participate in CAP and the potential roles of CAP. Table 1 presents limitations of current CAPs based on the analysis of all the results at the different levels.

Table 1. Limitations of current Community-based Adaptation Programs (CAPs).

\begin{tabular}{|c|c|c|}
\hline Policy Issues & $\begin{array}{l}- \\
- \\
-\end{array}$ & $\begin{array}{l}\text { Unclear operation of adaptation program at multiple levels of national, district, } \\
\text { community and individual. } \\
\text { Development of Nepal's climate policy is based on the Kyoto protocol rather than local } \\
\text { communities' requirements. } \\
\text { Uncertainty in how to involve mountain communities in CAP. }\end{array}$ \\
\hline Legal Issues & - & $\begin{array}{l}\text { CAP is not a legal instrument yet. } \\
\text { No direct communication between communities and responsible organizations for CAP. }\end{array}$ \\
\hline Economic/Finance Issues & $\begin{array}{l}- \\
- \\
-\end{array}$ & $\begin{array}{l}\text { Limitation of livelihood options and access to productive assets. } \\
\text { No specific tools to identify the economic development of CAP. } \\
\text { Difficulty in identifying vulnerable mountain communities. } \\
\text { Inequality in conducting the social security program. }\end{array}$ \\
\hline $\begin{array}{l}\text { Technology/Information } \\
\text { Issues }\end{array}$ & $\begin{array}{l}- \\
-\end{array}$ & $\begin{array}{l}\text { Lack of infrastructure to expand telecommunication channels. } \\
\text { Focus is on disseminating general information on climate change and not specific } \\
\text { adaptation practices for the local context. } \\
\text { No evidence in facilitating mountain communities in using IS. }\end{array}$ \\
\hline Social Issues & - & $\begin{array}{l}\text { Existing power relations promote inequality in accessing resources. } \\
\text { Conducting CAPs without looking at communities prerequisites (what is needed), } \\
\text { potentials (knowledge, capacity, asset, resources, information) and societal variables } \\
\text { (gender, cast, and ethnicity). }\end{array}$ \\
\hline
\end{tabular}


Overall, all results confirmed that IS and its requirements were not considered in CAP/s. Information on climate change risks from stakeholders and organizations is vital for adaptation planning [72]. Key experts at district offices, NGO, and national level recommended the need for disseminating information. Access to information (DLO, DFO, and DPO), raising awareness (DADO), having a source of weather data and information (DSO), establishing an information center (NGO, MoAD) and integration of climate change information with land data (MoLRM) are emphasized. The ministries need information about climate change and adaptation activities in the development of climate-related policies from other ministries and district offices. Furthermore, both communities and individuals mentioned the need for efficient and effective ways of communicating regarding climate change information and adaptation. Figure 3 represents categories of the services that the communities need to be shared or reported to the government, NGOs or other communities.

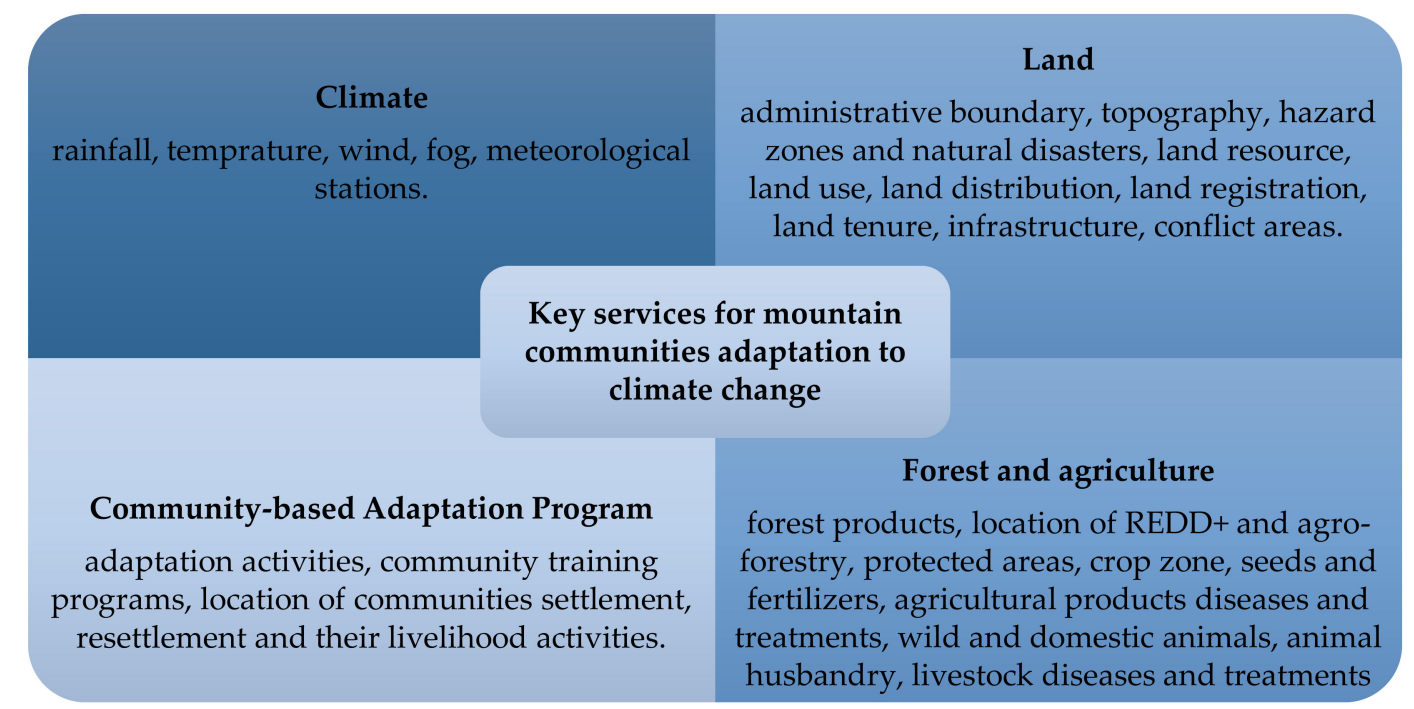

Figure 3. Key needed services.

\section{Conceptualizing MCAS}

Amongst the many issues raised, lack of information and information sharing stands out as a cross-cutting theme. The results of the analysis suggest the need for the introduction of an intervention strategy that increases access to climate information, addresses the resources available, identifies CAP and facilitates participation in CAP. These are the types of information that communities need to determine the potentials, improve their capacities, and adjust to the current/new situations. Furthermore, policymakers and CAP planners are concerned to know about the socio-economic impacts of climate change on a community to increase community adaptive capacity. Information is an influential factor regarding the effectiveness of both policymakers' choices in adaptation planning and communities in implementing CAPs. Information addresses the needs of a nation, an organization, a community and/or an individual. The flow of information adjusts the needs of stakeholders of $\mathrm{CAP} / \mathrm{s}$ since it answers "what, who, when, why and how" questions. A system creating and sharing such information could translate and disseminate this information to each stakeholder especially at the community level.

Land Information System (LIS), a subset of an information system, appear more suitable for managing the needs of users since they link an activity/s to a specific position [73]. LIS can collect, store, manage and disseminate spatial and non-spatial information regarding services to citizens. Integrating LIS with the emerging technologies including mobile and web-based tools support chances for sharing information [74]. It appears, LIS are highly suitable for application into CAPs: adaptation activities can be seen as a service for responding to the impacts of climate change, which fundamentally 
have a spatial extent. However, issues of security and data privacy, along with data and system maintenance must be considered in the context of any system development deemed sustainable. Moreover, the ability of mountain communities to access and use such an IS requires more thorough investigation. Dealing with obstacles and the digital divide is an inseparable part of any IS development initiative, particularly for the vulnerable people who are in the greatest need of help.

Going beyond the general notion of LIS and CAP, climate services address climate variability and climate events. A climate service is efficient when it is based on the users' need [75]. The concept of a Mountain Community Adaptive System (MCAS), an integrated land and climate change IS, that contributes to the service delivery of CAP/s is a possible response. Impacts of climate change cause or contribute to mountain communities/individuals vulnerability as they were identified in Sections 4.1-4.3. This is where we find the link to identify the needs of mountain communities as prioritized services in MCAS. Figure 4 presents the overview of MCAS. It shows how MCAS can contribute to providing land and climate change services to support mountain communities/individuals. It has the potential to assign rights to store, view, access, share and report information in CAP/s.

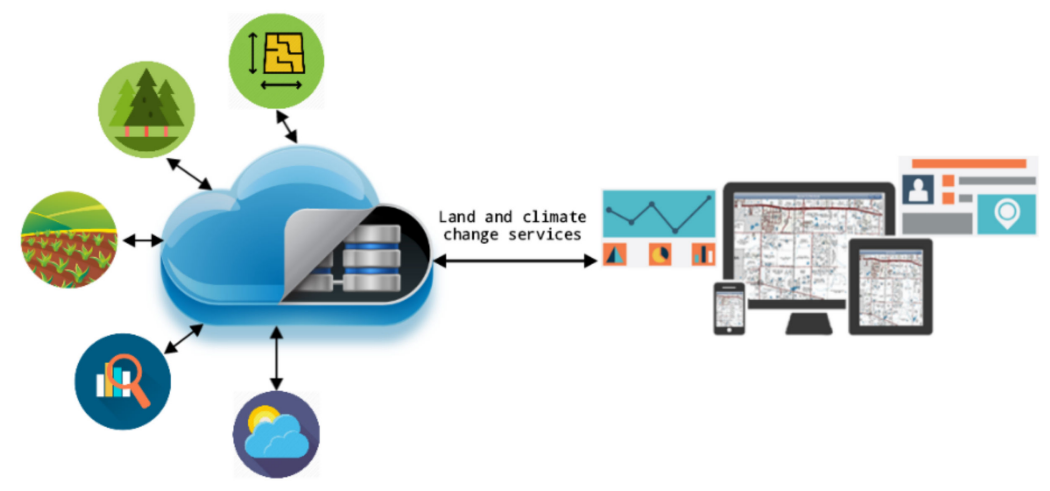

Figure 4. The overview of Mountain Community Adaptive System (MCAS).

The ministries provide data and services based on their institutional responsibilities and not because of CAP. MCAS can integrate these data and services to contribute to CAP. LIS allows different datasets "to be organized using geographic coordinates" and "to be grouped according to locations" [76]. Figure 3 presents key services for mountain communities. The prioritized climate services in the line of CAP were identified, based on the analysis of the field work. Not all of these services are crucial or used for MCAS. Some of the services require sponsors or customization for a specific activity/reason.

Rain and temperature are two critical factors that influence agriculture. Meeting this need is to make these variables accessible in a meaningful way called climate services. It provides essential climate information such as annual rain and temperature. They improve communities/individuals needs and/or interests. Mountain communities can identify wet/dry and/or warm/cool year/period to adjust their agricultural activities. DHM is observing this information so the closest meteorological station/s can be placed in MCAS.

Other certain requirements for the mountain communities/individuals include: (a) infrastructure such as road networks, water reservoirs, and hydro lines are important as they facilitate them in overcoming water deficit and quick access to the market, (b) land use category to identify forest land from agriculture and pasture lands, (c) information about villages, administrative boundaries and municipalities enable them to share their activities and problems with the relevant district offices, and (d) other CAP activities in the area which inspire them and allow exploring the possibilities of doing the same CAP. Furthermore, it connects them to the resources available in the closest area to overcome their shortage efficiently. MoFSC, MoAD, and MoLRM can share and combine their data to 
support these services to the mountain communities/individuals. A base map is necessary to locate all these spatial and non-spatial data. MoLRM is capable of providing a base map.

\section{Conclusions}

CAP is a popular approach for adaptation at local level, especially in climate-sensitive areas including mountains. Different adaptation options and tools are identified to assist communities/individuals in development and implementation of CAPs. The purpose of the CAP is to strengthen mountain communities' adaptive capacity. The study reveals that many CAPs are developed based on national level commitments that do not include necessary communities' requirements. Communities then remain vulnerable since they are still experiencing difficulty in accessing information about available resources and CAP. Information is an important factor to overcome communities' limitation. An Information System, particularly Land Information System (LIS), can deliver climate change adaptation service to communities. Mountain Community Adaptive System (MCAS) can integrate climate variable and prioritized services from different data and service providers to foster communities' abilities in CAP. The data and services to be included will be targeted to reduce the mountain communities' vulnerability.

Author Contributions: Conceptualization, all authors.; Methodology, all authors.; Software, A.K.; Formal Analysis, A.K.; Data Curation, A.K.; Writing-Original Draft Preparation, A.K.; Writing-Review \& Editing, all authors.; Supervision, R.B. And J.Z.; Funding Acquisition, J.Z. All authors provided feedback and contributed to finalize the manuscript.

Funding: This research was funded by Erasmus Mundus Action 2 Project SALAM, International Scholarship of the European Commission.

Acknowledgments: This research paper was conducted at Faculty of Geo-Information Science and Earth Observation (ITC), University of Twente. We appreciate participation of mentioned key experts of ministries of Nepal, Dolakha district offices, NGO, mountain communities/individuals of mentioned VDCs in FGI and household survey.

Conflicts of Interest: The authors declare no conflicts of interest.

\section{References}

1. Wilbanks, T.J.; Kates, R.W. Global change in local places: How scale matters. Clim. Chang. 1999, 43, 601-628. [CrossRef]

2. Schipper, E.L.F.; Ayers, J.; Reid, H.; Huq, S.; Rahman, A. Community-Based Adaptation to Climate Change: Scaling It up; Routledge: Abingdon, UK, 2014.

3. UNEP-WCMC. Mountain Watch: Environmental Change and Sustainable Development in Mountains; WCMC: Cambridge, UK, 2002.

4. Messerli, B. Global Change and the World's Mountains. Mt. Res. Dev. 2012, 32, 55-63. [CrossRef]

5. Castellari, S. Climate Change, Impacts and Adaptation Strategies in the Alpine Space: Some Results from the INTERREG III B Project ClimChAlp. In Proceedings of the International Conference on Mountains as Early Indicators of Climate Change, Padova, Italy, 17-18 April 2008.

6. UN. Agenda 21: Programme of Action for Sustainable Development; Rio Declaration on Environment and Development; Statement of Forest Principles; The Final Text of Agreements Negotiated by Governments. In Proceedings of the United Nations Conference on Environment and Development, Rio de Janerio, Brazil, 3-14 June 1992; United Nations Department of Public Information: New York, NY, USA, 1992.

7. Dodman, D.; Mitlin, D. Challenges for community-based adaptation: Discovering the potential for transformation. J. Int. Dev. 2013, 25, 640-659. [CrossRef]

8. Adger, W.N. Social Capital, Collective Action, and Adaptation to Climate Change. Econ. Geogr. 2003, 79, 387-404. [CrossRef]

9. Hardoy, J.; Romero Lankao, P. Latin American cities and climate change: Challenges and options to mitigation and adaptation responses. Curr. Opin. Environ. Sustain. 2011, 3, 158-163. [CrossRef] 
10. Noble, I.R.; Huq, S.; Anokhin, Y.A.; Carmin, J.; Goudou, D.; Lansigan, F.P.; Osman-Elasha, B.; Villamizar, A.; Ayers, J.; Berkhout, F.; et al. 14. Adaptation Needs and Options. In Climate Change 2014: Impacts, Adaptation and Vulnerability Part A Global and Sectoral Aspects; Assessment Report 5; IPCC: Geneva, Switzerland, 2014; pp. 833-868.

11. Lockemann, P.C. Information Systems: A Survey by Examples. In GI-5 Jahrestagung; Mülbacher, J., Ed.; Lecture Notes in Computer Science; Springer: Berlin/Heidelberg, Germany, 1975; Volume 34, pp. 3-34.

12. Silver, M.S.; Markus, M.L.; Beath, C.M. The Information Technology Interaction Model: A Foundation for the MBA Core Course. Manag. Inf. Syst. Q. 1995, 19, 361-390. [CrossRef]

13. Buhalis, D. Strategic use of information technologies in the tourism industry. Tour. Manag. 1998, 19, 409-421. [CrossRef]

14. Boell, S.K. Information: Fundamental positions and their implications for information systems research, education and practice. Inf. Organ. 2017, 27, 1-16. [CrossRef]

15. Ai, F.; Comfort, L.K.; Dong, Y.; Znati, T. A dynamic decision support system based on geographical information and mobile social networks: A model for tsunami risk mitigation in Padang, Indonesia. Saf. Sci. 2015, 90, 62-74. [CrossRef]

16. Goosen, H.; de Groot-Reichwein, M.A.M.; Masselink, L.; Koekoek, A.; Swart, R.; Bessembinder, J.; Witte, J.M.P.; Stuyt, L.; Blom-Zandstra, G.; Immerzeel, W. Climate Adaptation Services for the Netherlands: An operational approach to support spatial adaptation planning. Reg. Environ. Chang. 2013, 1-14. [CrossRef]

17. WMO. A Global Framework for Climate Services-Empowering the Most Vulnerable; WMO: Geneva, Switzerland, 2011.

18. Paul, B.; Rashid, H. Climatic Hazards in Coastal Bangladesh: Non-Structural and Structural Solutions, 1st ed.; Butterworth-Heinemann: Oxford, UK, 2016; 342p.

19. Klein, R.J.T.; Midgley, G.F.; Preston, B.L.; Alam, M.; Berkhout, F.G.H.; Dow, K.; Shaw, M.R.; Botzen, W.; Buhaug, W.; Butzer, K.W.; et al. 16. Adaptation Opportunities, Constraints, and Limits. In Climate Change 2014: Impacts, Adaptation and Vulnerability Part A Global and Sectoral Aspects; Assessment Report 5; IPCC: Geneva, Switzerland, 2014; pp. 899-943.

20. Mallick, B.; Vogt, J. Societal Dealings with Cyclone in Bangladesh-A Proposal of Vulnerability Atlas for Sustainable Disaster Risk Reduction. J. Coast. Zone Manag. 2015, 18. Available online: https:/ / www.omicsonline.com/open-access/societal-dealings-with-cyclone-in-bangladesha-proposalof-vulnerability-atlas-for-sustainable-disaster-risk-reduction-jczm-1000409.php?aid=57660 (accessed on 30 May 2018). [CrossRef]

21. Hoegh-Guldberg, O. Coral reef ecosystems and anthropogenic climate change. Reg. Environ. Chang. 2011, 11 (Suppl. 1), 215-227. [CrossRef]

22. Skoufias, E. The Poverty and Welfare Impacts of Climate Change; World Bank: Washington, DC, USA, 2013; pp. 1-146.

23. Agrawal, A.; Kononen, M.; Perrin, N. The Role of Local Institutions in Adaptation to Climate Change; Social Development Working Papers, No. 118; World Bank: Washington, DC, USA, 2009; 22p, Available online: http:/ / siteresources.worldbank.org/EXTSOCIALDEVELOPMENT/Resources/2443621164107274725/sdp118.pdf (accessed on 30 May 2018).

24. Mertz, O.; Halsnæs, K.; Olesen, J.E. Adaptation to Climate Change in Developing Countries. Environ. Manag. 2009, 43, 743-752. [CrossRef] [PubMed]

25. UKCIP. Making Progress; UKCIP: Oxford, UK, 2011.

26. UNFCCC/SBSTA. Report of the Subsidiary Body for Scientific and Technological Advice on Its Twenty-Fifth Session; UNFCCC: New York, NY, USA, 2007; Volume 60306.

27. Finzi Hart, J.; Grifman, P.; Moser, S.; Abeles, A.; Myers, M.; Schlosser, S.; Ekstrom, J.A. Rising to the Challenge: Results of the 2011 Coastal California Adaptation Needs Assessment. 2012. Available online: https:/ / caseagrant.ucsd.edu/publication/rising-to-the-challenge-results-of-the-2011california-coastal-adaptation-needs (accessed on 30 May 2018).

28. Preston, B.L.; Yuen, E.J.; Westaway, R.M. Putting vulnerability to climate change on the map: A review of approaches, benefits, and risks. Sustain. Sci. 2011, 6, 177-202. [CrossRef]

29. Burton, I.; Diringer, E.; Smith, J. Adaptation to Climate Change: International Policy Options; Pew Center on Global Climate Change: Arlington, VA, USA, 2006. 
30. Eisenack, K.; Stecker, R.; Reckien, D.; Hoffmann, E. Adaptation to climate change in the transport sector: A review of actions and actors. Mitig. Adapt. Strateg. Glob. Chang. 2012, 17, 451-469. [CrossRef]

31. Irfanullah, H.M.; Azad, M.A.K.; Kamruzzaman, M.; Wahed, M.A. Floating Gardening in Bangladesh: A means to rebuild lives after devastating flood. Indian J. Tradit. Knowl. 2011, 10, 31-38.

32. Pramova, E.; Locatelli, B.; Brockhaus, M.; Fohlmeister, S. Ecosystem Services in the National Adaptation Programmes of Action. Clim. Policy 2012, 12, 393-409. Available online: http:/ / www.tandfonline.com/doi/ abs /10.1080/14693062.2011.647848\#.VbeQIflViko (accessed on 30 May 2018). [CrossRef]

33. Van Aalst, M.K.; Cannon, T.; Burton, I. Community level adaptation to climate change: The potential role of participatory community risk assessment. Glob. Environ. Chang. 2008, 18, 165-179. [CrossRef]

34. De Bruin, K.; Dellink, R.B.; Ruijs, A.; Bolwidt, L.; Van Buuren, A.; Graveland, J.; de Groot, R.S.; Kuikman, P.J.; Reinhard, S.; Roetter, R.P.; et al. Adapting to climate change in the Netherlands: An inventory of climate adaptation options and ranking of alternatives. Clim Chang. 2009, 95, 23-45. [CrossRef]

35. Sultana, Z.; Mallick, B. Adaptation Strategies after Cyclone in Southwest Coastal Bangladesh-Pro Poor Policy Choices. Available online: http://pubs.sciepub.com/ajrd/3/2/2/index.html (accessed on 30 May 2018).

36. Adaptation Fund Board. Operational Policies and Guidelines for Parties to Access Resources from the Adaptation Fund; The Adaptation Fund: Washington, DC, USA, 2013; p. 39.

37. Burton, I.; Malone, E.L.; Huq, S. Adaptation Policy Framework for Climate Change: Developing Strategies, Policies and Measures; Lim, B., Spanger-siegfried, E., Eds.; Cambridge University Press: Cambridge, UK, 2004.

38. UNFCCC. Compendium on Methods and Tools to Evaluate Impacts of, Vulnerability and Adaptation to Climate Change; UNFCCC: New York, NY, USA, 2004.

39. Eikelboom, T.; Janssen, R. Collaborative use of geodesign tools to support decision-making on adaptation to climate change. Mitig. Adapt. Strateg. Glob. Chang. 2015, 247-266. [CrossRef]

40. IISD. CRiSTAL User's Manual, version 5; 2012. Available online: http:/ / www.iisd.org/library/cristal-usersmanual-version-5-community-based-risk-screening-tool-adaptation-and (accessed on 30 May 2018).

41. SERVIR. ServierGlobal. 2015. Available online: https:/ / www.servirglobal.net/ (accessed on 18 May 2015).

42. weADAPT. About weADAPT. 2016. Available online: https://www.weadapt.org/knowledge-base/ guidance/about-weadapt (accessed on 1 January 2017).

43. ALM (Adaptation Learning Mechanism). About ALM. 2017. Available online: http://www. adaptationlearning.net/about (accessed on 1 January 2017).

44. AfricaAdapt. 2015. Available online: http://www.africa-adapt.net/en-us/about/ (accessed on 1 January 2017).

45. Castro, J.; Kolp, M.; Mylopoulos, J. Towards requirements-driven information systems engineering: The Tropos project. Inf. Syst. 2002, 27, 365-389. [CrossRef]

46. Westerhoff, L.; Keskitalo, E.C.H.; Juhola, S. Capacities across scales: Local to national adaptation policy in four European countries. Clim. Policy 2011, 11, 1071-1085. [CrossRef]

47. Preston, B.L.; Westaway, R.M.; Yuen, E.J. Climate adaptation planning in practice: An evaluation of adaptation plans from three developed nations. Mitig. Adapt. Strateg. Glob. Chang. 2011, 16, 407-438. [CrossRef]

48. Weaver, C.P.; Lempert, R.J.; Brown, C.; Hall, J.A.; Revell, D.; Sarewitz, D. Improving the contribution of climate model information to decision making: The value and demands of robust decision frameworks. Wiley Interdiscip. Rev. Clim. Chang. 2013, 4, 39-60. [CrossRef]

49. Pensa, S.; Masala, E.; Lami, I.M.; Zhou, R.; Su, H.; Wang, X.; Hu, Y.; Zhang, F. Planning Support Systems for Sustainable Urban Development; Springer: Berlin, Germany, 2013.

50. Kirchhoff, C.J.; Lemos, M.C.; Dessai, S. Actionable Knowledge for Environmental Decision Making: Broadening the Usability of Climate Science. Annu. Rev. Environ. Resour. 2013, 38, 393-414. [CrossRef]

51. Lemos, M.C.; Kirchhoff, C.J.; Ramprasad, V. Narrowing the climate information usability gap. Nat. Clim. Chang. 2012, 2, 789-794. [CrossRef]

52. Yin, R.K. Case Study Research: Design and Methods, 5th ed.; Sage: London, UK, 2014; p. 282.

53. GLOBE International. Climate Legislation Study: A Review of Climate Change Legislation in 33 Countries, 3rd ed.; Townshend, T., Fankhauser, S., Aybar, R., Collins, M., Landesman, T., Nachmany, M., Pavese, C., Eds.; GLOBE International: Melbourne, Australia, 2013. 
54. Kreft, S.; Eckstein, D.; Melchior, I. Global Climate Risk Index 2017; Germanwatch e.V., Office Bonn Dr. Werner-Schuster-Haus: Berlin, Germany, 2017; Available online: www.germanwatch.org/en/cri (accessed on 30 May 2018).

55. ND-GAIN (The Notre Dame Global Adaptation Initiative). 2015. Available online: http://index.gain.org/ (accessed on 1 January 2017).

56. Hunzai, K.; Gerlitz, J.; Hoermann, B.; Kollmair, M. Understanding Mountain Poverty: Exploring the Specificities of Poverty in the Mountain Areas of the Greater Himalayan Region; ICIMOD: Patan, Nepal, 2010; p. 5.

57. DataUN. 2015. Available online: http://data.un.org/CountryProfile.aspx?crName=Nepal\#Summary (accessed on 1 January 2015).

58. Maw, S.J.; Mauchline, A.L.; Park, J.R. Biological Fieldwork Provision in Higher Education. Biosci. Educ. 2011, 17, 1-14. [CrossRef]

59. Ministry of Environment. Climate Change Vulnerability Mapping for Nepal. Ministry of Environment: Kathmandu, Nepal, 2010.

60. GoN. Table of Population Atlas of Nepal 2014. Central Bureau of Statistics: Kathmandu, Nepal, 2014; Volume 53.

61. OpenNepal. District Details. 2015. Available online: http://data.opennepal.net/districts/dolakha (accessed on 12 September 2015).

62. World Weather Online. 2017. Available online: https://www.worldweatheronline.com/dolakha-weatheraverages/np.aspx (accessed on 1 January 2017).

63. HDX. District-Profile-Census-2011. 2015. Available online: https://data.humdata.org/ (accessed on 7 April 2016).

64. Bryman, A. Social Research Methods, 5th ed.; Oxford University Press: Oxford, UK, 2016; 747p.

65. Ministry of Environment. Government of Nepal National Adaptation Programme of Action to Climate Change. Government of Nepal, Ministry of Environment: Kathmandu, Nepal, 2010; pp. 1-96.

66. UN/ECE. Land Adminstration Guidlines with Special Reference To countries in Transition; United Nations: New York, NY, USA; Geneva, Switzerland, 1996.

67. Niraula, R.R.; Gilani, H.; Pokharel, B.K.; Qamer, F.M. Measuring impacts of community forestry program through repeat photography and satellite remote sensing in the Dolakha district of Nepal. J. Environ. Manag. 2013, 126, 20-29. [CrossRef] [PubMed]

68. Government of Nepal. Climate Change Adaptation and Disaster Risk Management in Agriculture Priority Framework for Action. Government of Nepal: Kathmandu, Nepal, 2011.

69. Kumar, R. Research Methodology: A Step-by-Step Guide for Beginners, 4th ed.; Sage: London, UK, 2014; 399p.

70. Friese, S. Qualitative Data Analysis with ATLAS.ti; Sage: London, UK, 2014; p. 296.

71. GoN. Climate Change Policy, 2011. Government of Nepal: Kathmandu, Nepal, 2011.

72. Mimura, N.; Pulwarty, R.S.; Duc, D.M.; Elshinnawy, I.; Redsteer, M.H.; Huangm, H.-Q.; Nkem, J.N.; Rodriguez, R.A.S.; van Aalst, M.; Donahue, J.; et al. Adaptation planning and implementation. In Climate Change 2014: Impacts, Adaptation, and Vulnerability Part A: Global and Sectoral Aspects WGII to the Fifth Assessment Report of IPCC; Field, C.B., Barros, V.R., Dokken, D.J., Mach, K.J., Mastrandrea, M.D., Bilir, T.E., Chatterjee, M., Ebi, K.L., Estrada, Y.O., Genova, R.C., et al., Eds.; Cambridge University Press: Cambridge, UK, 2014.

73. Wallace, J.; Marwick, B.; Bennett, R.; Rajabifard, A.; Williamson, I.; Tambuwala, N.; Potts, K.; Agunbiade, M. Spatially Enabling Land Administration: Drivers, Initiatives and Future Directions for Australia. Spat. Enabling Soc. Res. Emerg. Trends Crit. Assess. 2010, 55-68. Available online: http://hdl.handle. net/11343/28948 (accessed on 30 May 2018).

74. Williamson, I.; Enemark, S.; Wallace, J.; Rajabifard, A. Land Administration for Sustainable Development; Esri Press: Redlands, CA, USA, 2010; 487p.

75. Hewitt, C.; Mason, S.; Walland, D. The Global Framework for Climate Services. Nat. Clim. Chang. 2012, 2, 831-832. [CrossRef]

76. Bennett, R.; Wallace, J.; Williamson, I. Organising land information for sustainable land administration. Land Use Policy 2008, 25, 126-138. [CrossRef]

(C) 2018 by the authors. Licensee MDPI, Basel, Switzerland. This article is an open access article distributed under the terms and conditions of the Creative Commons Attribution (CC BY) license (http:// creativecommons.org/licenses/by/4.0/). 